\title{
MENINGKATKAN KEMAMPUAN KOMUNIKASI DAN KONEKSI MATEMATIK SISWA SMP MELALUI STRATEGI THINK TALK WRITE
}

Fitria Nurapriani

fitria.apriani@ubpkarawang.ac.id

Universitas Buana Perjuangan Karawang

\begin{abstract}
Abstrak
Tujuan penelitian ini adalah untuk menelaah pencapaian dan peningkatan kemampuan pemahaman dan komunikasi matematik siswa SMP dengan pendekatan pembelajaran induktif dan dengan pembelajaran biasa. Penelitian ini merupaka kuasi eksperimen dengan desain tes pretest dan postest. Pengmabilan sampel dalam penelitian ini menngunakan sampel yang dipilih kelas yaitu terdiri dari siswa kelas VII sebanyak 31 kelas eksperimen dan 31 siswa kelas kontrol. Metode pengumpulan data adalah tes, instrumen tes mencakup tes kemampuan komunikasi dan kemampuan koneksi matematik
\end{abstract}

Kata kunci : Strategi TTW, kemampuan Komunikasi dan koneksi siswa

\section{PENDAHULUAN}

Matematika adalah bahasa simbol di mana setiap orang yang belajar matematika dituntut untuk mempunyai kemampuan untuk berkomunikasi dengan menggunakan bahasa simbol tersebut. Kemampuan komunikasi matematik akan membuat seseorang bisa memanfaatkan matematika untuk kepentingan diri sendiri maupun orang lain, sehingga akan meningkatkan sikap positif terhadap matematika baik dari dalam diri sendiri maupun orang lain. Sumarmo (Anggoro, 2014) mengemukakan bahwa matematika sebagai bahasa simbol mengandung makna bahwa matematika bersifat universal dan dapat dipahami oleh setiap orang kapan dan di mana saja. Setiap simbol mempunyai arti yang jelas, dan disepakati secara bersama oleh semua orang. Sebagai contoh simbol operasi,,+- berlaku secara nasional disetiap jenjang sekolah di mana pun sehingga dapat dipahami oleh semua orang.

Kemampuan komunikasi menjadi penting ketika diskusi antar siswa dilakukan, siswa diharapkan mampu menyatakan, menjelaskan, menggambarkan, mendengarkan, menanyakan dan bekerjasama sehingga dapat membawa siswa pada pemahaman yang mendalam tentang matematika. Anak-anak yang diberikan kesempatan untuk bekerja dalam kelompok dalam mengumpulkan dan menyajikan data, diharapkan mereka dapat menunjukan kemajuan disaat mereka saling mendengarkan ide yang satu dan yang lain, mendiskusikannya bersama kemudian menyusun kesimpulan yang menjadi pendapat kelompoknya. 
Dalam dunia pendidikan terutama dalam pembelajaran matematika kemampuan menghubungkan suatu materi yang satu dengan materi yang lain atau dengan kehidupan seharihari berperan penting dalam proses pembelajaran. Didalam matematika memuat beberapa kemampuan yang diharapkan dapat dikuasai siswa, salah satunya adalah kemampuan dalam melakukan koneksi matematik. Melalui kemampuan koneksi matematik, kemampuan berfikir siswa terhadap matematika diharapkan dapat menjadi semakin luas. Selain itu, koneksi matematik dapat pula meningkatkan kemampuan kognitif siswa seperti mengingat kembali, memahami penerapan suatu konsep terhadap lingkungan dan sebagainya. Tanpa menerapkan konsep dengan pengalaman siswa, maka ia akan susah mengingat suatu materi yang disampaikan dan mengingat terlalu banyak konsep yang terpisah padahal matematika kaya akan prinsip-prinsip. Koneksi matematis berasal dari Bahasa Inggris yaitu dari kata Mathematical Connection yang kemudian dipopulerkan NCTM pada tahun 1989 dan dijadikan sebagai salah satu standar kurikulum Sartika (Gunawan, 2013) apa yang bertujuan membantu pembentukan persepsi siswa, dengan cara melihat matematika sebagai suatu keseluruhan yang padu bukan sebagai materi yang berdiri sendiri-sendiridan mengenal relevansi dan manfaat matematika baik disekolah maupun diluar sekolah.

Kenyataan di lapangan menunjukkan bahwa keterampilan komunikasi matematik tersebut belum dilatih secara maksimal. Seringkali siswa tidak terbiasa melibatkan diri secara aktif dalam pembelajaran. Dikarenakan oleh belum tersedianya soal-soal yang mengukur kemampuan komunikasi matematis sehingga soal-soal yang selama ini diberikan kepada siswa adalah soalsoal yang hanya menyelesaikannya secara prosedur matematik, tidak memberi kesempatan kepada siswa untuk mengkomunikasikannya secara lisan ataupun tertulis sehingga kemampuan siswa dalam mengkomunikasikan ide atau konsep matematika menjadi sangat lemah.

Sesuai dengan kenyataan di lapangan, khususnya di Indonesia banyak siswa yang masih kesulitan mengkoneksikan antara konsep yang sedang dipelajari dengan konsep yang telah dimiliki oleh siswa. jika siswa mampu mengoneksikan konsep yang sedang dipelajari dengan konsep telah dimiliki oleh siswa maka pembelajaran bermakna akan dicapai. Selain itu, siswa pun masih kesulitan mengaitkan materi matematika yang sedang mereka pelajari dengan permasalahan dalam kehidupan sehari-hari, serta tidak mengetahui hubungan antar konsep.

Strategi mengajar menyangkut pemilihan cara yang dipilih guru dalam menentukan ruang lingkup, urutan bahasan, kegiatan pembelajaran, dan lain-lain dalam menyampaikan materi matematika kepada siswa di depan kelas Hudoyo (Andriani, 2008). Think talk write adalah strategi yang memfasilitasi latihan berbahasa secara lisan dan menulis bahasa tersebut dengan lancar. Strateg think talk write didasarkan pada pemahaman bahwa belajar adalah sebuah perilaku sosial. Strategi think talk write mendorong siswa untuk berfikir, berbicara, dan 
kemudian menuliskan berkenaan dengan suatu topik. Strategi think talk write digunakan untuk mengembangkan tulisan dengan lancar dan melatih bahasa sebelum menuliskannya. Strategi think talk write memperkenankan siswa untuk mempengaruhi dan memanipulasi ide-ide sebelum menuliskannya.

Think Talk Write adalah strategi yang memfasilitasi latihan berbahasa secara lisan dan bahasa tersebut dengan lancar. Strategi yang diperkenalkan pertama kali oleh Huinker dan Laughlin ( Huda, 218: 2013) ini didasarkan pada pemahaman bahwa belajar adalah sebuah prilaku sosial. Strategin Think Talk Write mendorong siswa untuk berpikir, berbicara, dan kemudian menuliskan suatu topik tertentu. Strategi ini digunakan untuk mengembangkan tulisan dengan lancar dan melatih bahasa sebelum dituliskan. Strategi Think Talk Write memperkenankan siswa untuk mempengaruhi memanipulasi ide-ide sebelum menuangkannya dalam bentuk tulisan. Ia juga membantu siswa dalam mengumpulkan dan mengembangkan ideide melalui percakapan terstruktur.

Menurut beberapa hasil penelitian strategi Think talk write merupakan salah stau strategi pembelajaran yang dapat digunakan untuk meningkatkan kemampuan komunikasi matematik siswa. Huinker (Weti, 2010) menyebutkan bahwa berfikir (Think) dan bicara (Talk) merupakan suatu langkah yang penting bagi siswa dalam proses membawa mereka ke tahap menulis (Write). Strategi Think Talk Write sangat mendukung dalam upaya peningkatan kemampuan komunikasi matematik siswa. Dalam hal ini Ansari (Weti, 2010) mengemukakan bahwa esensi dari Think Talk Write adalah mengedepankan perlunya siswa mengkomunikasikan atau menjelaskan hasil pemikirannya mengenai masalah yang diberikan oleh guru. Hal lain yang dapat menunjukan hubungan antara strategi Think Talk Write dengan komunikasi matematik adalah bahwa diantara faktor-faktor yang berkaitan dengan kemampuan komunikasi matematika adalah diskusi (bicara) dan menulis Ansari (Think Talk Write). Selain itu aspek dari komunikasi, bahwa pembelajaran dapat membantu siswa untuk mengkomunikasikan ide-ide matematik dengan mempresentasi, mendengar, membaca berdiskusi dan menulis. Berdasarkan uraian diatas mengenai peranan dan keutamaan Think Talk Write serta tugas-tugas yag dilakukan siswa dalam menggunakan strategi ini, diharapkan bahwa pembelajaran dengan strategi Think Talk Write dapat menumbuhkan kemampuan komunikasi matematik.

Salah satu solusi dari permasalahan-permasalahan di atas adalah pembelajaran matematika di sekolah dengan menggunakan strategi Think Talk Write yang diupayakan dapat membuat siswa aktif serta berkomunikatif dalam proses belajar mengajar pada mata pelajaran matematika. Melalui keterlibatan siswa secara aktif tersebut, maka diharapkan kemampuan komunikasi dan koneksi matematik siswa akan dapat terlatih dengan baik. Karena itu penelitian 
ini di berikan judul Meningkatkan Kemampuan Komunikasi dan Koneksi Matematik Siswa SMP melalui Strategi Think Talk Write.

\section{TINJAUAN PUSTAKA}

\section{A. Kemampuan Komunikasi Matematik}

Komunikasi matematik merupakan kemampuan matematik esensial yang tercantum dalam kurikulum matematika sekolah menengah NCTM dan KTSP (Sumarmo, 445: 2013). Komponen tujuan pembelajaran matematika tersebut antara lain : dapat mengkomnikasikan gagasan dengan simbol, tabel, diagram atau ekspresi matematik untuk memperjelas keadaan masalah, dan memiliki sikap menghargai kegunaan matematika dalam kehidupan, sikap rasa ingin tahu, perhatian dan minat dalam mempelajari matematika, serta sikap ulet dan percaya diri dalam pemecahan masalah. Selain tercantum dalam kurikulum matematika sekolah, pengembangan kemampuan komunikasi matematik juga sesuai dengan hakekat matematika sebagai bahasa simbol yang efisien, padat makna memiliki sifat keteraturan yang indah dan kemampuan analisis kuantitatif, bersifat universal dan dapat dipahami oleh setiap orang kapan dan di mana saja, dan membantu menghasilkan model matematika yang diperlukan dalam pemecahan masalah berbagai cabang ilmu pengetahuan dan masalah kehidupan sehari-hari. Setiap simbol matematik mempunyai arti jelas, dan disepakati secara bersama oleh semua orang. Sifat universal dari simbol matematik, misalnya terlukis dalam contoh simbol bilangan 9, operasi,$+ \mathrm{x}$, - berlaku ditiap jenjang sekolah di manapun dan dapat dipahami oleh semua orang yang belajar matematika.

Pentingnya pemilikan kemampuan komunikasi matematik antara lain dikemukakan Yonandi (Sumarmo, 446: 2013) dengan rasional : a) Matematika adalah bahasa esensial yang tidak hanya sebagai alat berpikir, menemukan rumus, menyelesaikan masalah, atau menyimpulkan saja, namun matematika juga memiliki nilai yang tidak terbatas untuk menyatakan beragam ide secara jelas, teliti dan dan tepat; b) Matematika dan belajar matematika adalah jantungnya kegiatan sosial manusia, misalnya dalam pembelajaran matematika interaksi antara guru dan siswa, antara siswa dan siswa, antara bahan pembelajaran matematika dan siswa adalah faktor-faktor penting dalam memajukan potensi siswa. Peran penting, lainya dari pemikiran kemampuan komunikasi matematik dikemukakan Yonandi (Sumarmo, 446: 2013) yaitu : membantu siswa menajamkan cara siswa berpikir, sebagai alat untuk menilai pemahaman siswa, membantu siswa mengorganisasi pengetahuan matematiknya, meningkatkan kemampuan pemecahan masalah matematik, memajukan penalarannya, 
membangun kemampuan diri, meningkatkan keterampilan sosialnya, serta bermanfaat dalam mendirikan komunitas matematik.

Berdasarkan analisis terhadap beberapa tulisan, (Sumarmo, 446: 2013) mengidentifikasi indikator komunikasi matematik yang meliputi kemampuan : a) Menghubungkan benda nyata, gambar, dan diagram ke dalam ide matematika ; b) menjelaskan ide, situasi, dan relasi matematik, secara lisan dan tulisan dengan benda nyata, gambar, grafik, dan aljabar ; c) Menyatakan peristiwa sehari-hari dalam bahasa atau simbol matematika; d ) Mendengarkan, berdiskusi, dan menulis tentang matematika ; e) Membaca dengan pemahaman suatu presentasi matematika ; f)Menyusun konjektur, menyusun argumen, merumuskan definisi, dan generalisasi; g) Mengungkapkan kembali suatu uaraian atau paragrap matematika dalam bahasa sendiri.

Sedangkan indikator kemampuan siswa dalam komunikasi matematik pada pembelajaran matematika berdasarkan NCTM ( Lanani, 22: 2013) dapat dilihat dari : (1) Kemampuan mengekspresikan ide-ide matematika melalui lisan, tulisan, dan mendemonstrasikannya serta menggambarkannya secara visual; (2) Kemampuan memahami, menginterpretasikan, dan mengevaluasi ide-ide Matematika baik secara lisan maupun dalam bentuk visual lainnya; (3) Kemampuan dalam menggunakan istilah-istilah, notasinotasiMatematika dan struktur-strukturnya untuk menyajikan ide, menggambarkan hubunganhubungan dan model-model situasi.

Jenis kemampuan komunikasi matematik ini meliputi (Sumarmo, 5: 2013):

a. Menghubungkan benda nyata, gambar, dan diagram kedalam ide matematika.

b. Menjelaskan ide, situsi dan relasi matematik, secara lisan atau tulisan, dengan benda nyata, gambar, grafik dan aljabar.

c. Menyatakan peristiwa sehari-hari dalam bahasa atau simbol matematika.

d. Mendengarkan, berdiskusi, dan menulis tentang matematika.

e. Membaca presentasi matematik tertulis dan menyusun pertanyaan yang relevan.

f. Membuat konjektur, menyusun argumen, merumuskan definisi dan generalisai.

Kemampuan komunikasi matematik antara lain meliputi proses-proses matematik berikut Eliot dan Keney, Eds, NCTM (Sumarmo, 35: 2013) :

a. Menyatakan suatu situasi atau masalah matematik atau kehidupan sehari-hari ke dalam bentuk gambar, diagram, bahasa atau simbol matematik, atau model matematik.

b. Menjelaskan suatu idea matematik dengan gambar, ekpresi, atau bahasa sendiri atau secara lisan atau tulisan.

c. Membuat suatu cerita berdasarkan gambar, diagram, atau model matematik yang diberikan.

d. Menyusun pertanyaan tentang konten matematik yang diberikan. 


\section{B. Kemampuan Koneksi Matematik}

Koneksi matematik berasal dari Bahasa Inggris yaitu dari kata Mathematical Connection yang kemudian dipopulerkan NCTM pada tahun 1989 dan dijadikan sebagai salah satu standar kurikulum Sartika(Gunawan, 2013) yang bertujuan membantu pembentukan persepsi siswa, dengan cara melihat matematika sebagai suatu keseluruhan yang padu bukan sebagai materi yang berdiri sendiri-sendiridan mengenal relevansi dan manfaat matematika baik disekolah maupun diluar sekolah.

Menurut Suherman (Gunawan, 2013), "Kemampuan koneksi dalam matematika adalah kemampuan untuk mengkaitkan konsep/aturan matematika yang satu dengan yang lainnya, dengan bidang studi lain, atau dengan aplikasi pada kehidupan nyata". Koneksi matematik mengacu kepada pemahaman yang mengharuskan siswa dapat mernperlihatkan hubungan antara topik matematika. Sedangkan hubungan ekstrnal matematika meliputi hubungan antara matematika dengan bidang studi lain dan dengan kehidupan sehari-hari.

Salah satu pentingnya siswa diberikan latihan-latihan yang berkenaan dengan soal-soal koneksi adalah bahwa dalam matematika setiap konsep berkaitan satu sama lain, seperti dalildengan dalil, antara teori-dengan teori, antara topik-dengan topik, dan antara cabang-cabang matematika. Hal ini sejalan dengan pendapat Bruner dalam Russefendi (Gunawan, 2013) yang mengemukakan bahwa; "Dalam matematika setiap konsep itu berkaitan dengan konsep lain. Begitu pula antara yang lainnnya misalnya antara dalil dengan dalil, antara teori dan teori, antara topik denan topik, antara cabang matematika. Oleh karena itu, agar siswa berhasil belajar matematika, siswa harus lebih banyak diberi kesempatan untuk melihat kaitan-kaitan itu".

Jenis kemampuan koneksi meliputi (Sumarmo, 6: 2013) :

a. Mencari hubungan berbagai representasi konsep dan prosedur.

b. Memahami hubungan antar topik matmatika.

c. Menggunakan matematika dalam bidang studi lain atau kehidupan sehari-hari.

d. Memahami representasi ekuivalen konsep atau prosedur ke prosedur yang sama.

e. Mencari koneksi satu prosedur ke prosedur lain dalam representasi yang ekuivalen.

f. Menggunakan koneksi antar topik matematika dan antar topik matematika dengan topik lain.

NCTM (Sumarmo, 37: 2013) kemampuan koneksi matematik meliputi kemampuan :

a. Mencari representasi ekuivalen konsep dan prosedur yang sama

b. Memahami hubungan antar topik matematika

c. Menggunakan matematika dalam bidang studi lain atau kehidupan sehari-hari 
Koneksi matematik merupakan kemampuan dasar mengaplikasikan konsep matematika dalam penyelesaian masalah nyata. Dalam belajar matematika siswa hendaknya memahami koneksi antara ide-ide matematik, dan antara matematik dan bidang studi lainunya. Koneksi matematik dapat tergolong pada berpikir tingkat rendah atau tingkat tinggi bergantung pada kekompleksan kegiatan yang terlibat. Kemampuan yang tergolong pada koneksi matematik diantaranya adalah : menerapkan matematika dalam bidang lain atau dalam kehidupan seharihari, mencari hubungan berbagai representasi konsep dan prosedur, memahami hubungan antar topik matematika, memahami representasi ekuivalen suatu konsep, dan mencari hubungan satu prosedur dengan prosedur lain dalam representasi yang ekuivalen (Sumarmo, 198-99: 2013).

Kemampuan koneksi matematik merupakan kemampuan esensial yang harus dikuasai siswa sekolah menengah. Pentingnya pemikiran kemampuan koneksi matematik terkandung dalam tujuan pembelajaran matematika sekolah menengah (KTSP, NCTM, 1989), yaitu : Memahami konsep matematika, menjelaskan keterkaitan antar konsep dan mengaplikasikan konsep atau algoritma secara luwes, akurat, efisien, dan tepat dalam pemecahan masalah. Dalam rumusan tujuan tersebut, kemampuan koneksi matematik menjadi sangat penting karena akan membantu penguasaan pemahaman konsep yang bermakna dan membantu menyelesaikan tugas pemecahan masalah melalui keterkaitan antar konsep matematika dan antar konsep matematika dan antar konsep matematika dengan konsep dalam disiplin lain. Demikian pula kemampuan koneksi matematik ini akan membantu siswa dalam menyusun model matematik yang juga menggambarkan keterkaitan antar konsep dan atau data suatu masalah atau situasi yang diberikan. Berdasarkan analisis beberapa tulisan, Sumarmo, 2004 (Sumarmo, 443: 2013) merangkumkan kegiatan yang terlibat dalam tugas koneksi matematik yaitu sebagi berikut :
a. Memahami representasi ekuivalen suatu konsep, proses, atau prosedur matematik.
b. Mencari representasi ekuivalen suatu konsep, proses, atau prosedur matematik.
c. Memahami hubungan antar topik matmatika.
d. Menerapkan matematika dalam bidang lain atau dalam kehidupan sehari-hari.
e. Mencari hubungan satu prosedur dengan prosedur laindalam representasi yang ekuivalen.
f. Menerapkan hubungan antar topik matematika dan antar topik matematika dengan topik disiplin ilmu lainnya.




\section{METODE PENELITIAN}

Metode yang digunakan dalam penelitian ini adalah metode eksperimen semu (quasi eksperimental) dengan perlakuan yang diberikan adalah strategi Think Talk Write, dan variabel yang diukurnya adalah kemampuan komunikasi dan koneksi.

Subyek populasi penelitian ini adalah siswa kelas VII di satu SMPN di Kabupaten Karawang. Pada penelitian ini diambil dua kelas sebagai sampel dari tujuh kelas yang ada. Sampel yang digunakan sebanyak 62 siswa dengan rincian 31 siswa di kelompok eksperimen dan 31 siswa di kelompok kontrol. Kelompok eksperimen diajarkan dengan menggunakan pendekatan TTW, sedangkan kelompok kontrol diajarkan menggunakan pembelajaran konvensional.

Penelitian ini menggunakan desain penelitian pretest dan posttest dengan instrumen penelitian berupa tes kemampuan koneksi dan komunikasi matematik. Desain ini terdiri atas dua kelompok yang dipilih secara purposif. Pada awal penelitian dilakukan pretest dan pada akhir penelitian dilakukan posttest. Tes disusun dalam bentuk uraian terdiri dari enam butir soal.. Penilaian bukan hanya pada jawaban akhir saja tetapi pada setiap langkah yang ditempuh siswa diberi nilai. Hasil tes siswa akan diolah dengan menggunakan pengujian hipotesis mengenai perbedaan dua rata-rata skor pretest kemudian posttest dan yang terakhir gain ternormalisasi $(N$ Gain) antara kelompok eksperimen dan kelompok kontrol. Sebelum ditetapkan sebagai instrumen untuk penelitian, soal tes kemampuan penalaran matematik tersebut diujicobakan kepada siswa kelas VIII.

\section{HASIL DAN PEMBAHASAN}

Telah disebutkan beberapa rumusan masalah, sebagai jawaban terhadap rumusan masalah tersebut maka akan dianalisis tentang peningkatan dan pencapaian kemampuan komunikasi dan koneksi matematik siswa yang memperoleh pembelajaran dengan strategi Think Talk Write dan siswa yang memperoleh pembelajaran biasa. Selain dijelaskan tentang peningkatan dan pencapaian kemampuan komunikasi dan koneksi matematik siswa, dijelaskan pula pencapaian disposisi matematik siswa sebagai sikap siswa terhadap pembelajaran matematika terhadap kelompok yang yang memperoleh pembelajaran dengan strategi Think Talk Write dan siswa yang memperoleh pembelajaran biasa.

Data yang dianalisis terdiri dari : (a) data kemampuan komunikasi matematik ; (b) data kemampuan koneksi matematik ; (c) data gain ternormalisasi ; Data-data tersebut diperoleh dari hasil pretes dan postes. Pretes diberikan sebelum pembelajaran dengan tujuan untuk mengetahui 
kemampuan awal siswa baik kelas eksperimen maupun kelas kontrol. Kemampuan yang diamaksud adalah kemampuan komunikasi dan koneksi matematik. Postes diberikan setelah pembelajaran diberikan dengan tujuan untuk mengetahui peningkatan kemampuan komunikasi dan koneksi matematik siswa. Peningkatan kemampuan komunikasi dan koneksi matematik siswa pada kelas eksperimen dan kelas kontrol dilihat dari data gain yang diformulasikan oleh Meltzer (Afrilianto, 2012) yang ditinjau berdasarkan kemampuan siswa.

Kemampuan awal dan kemampuan akhir siswa yang dianalisis dalam penelitian ini adalah kemampuan komunikasi dan koneksi matematik siswa pada materi perbandingan dan skala. Pengolahan data yang dilakukan menggunakan Minitab 14 dan Microsoft Excel 2007. Adapun hasil pretes dan postes disajikan dalam Tabel 4.1 berikut ini.

Tabel 4.1

Deskripsi Hasil Pengolahan Data Kemampuan komunikasi dan Koneksi serta Disposisi Matematik Siswa

\begin{tabular}{|c|c|c|c|c|c|c|c|}
\hline \multirow{3}{*}{ Variabel } & \multirow{3}{*}{ 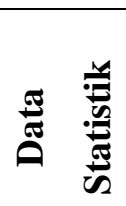 } & \multicolumn{6}{|c|}{ Pembelajaran } \\
\hline & & \multicolumn{3}{|c|}{ Strategi Think Talk Write } & \multicolumn{3}{|c|}{ Pembelajaran Biasa } \\
\hline & & Pretes & Postes & N-Gain & Pretes & Postes & N-Gain \\
\hline \multirow{5}{*}{$\begin{array}{l}\text { Kemampuan } \\
\text { Komunikasi } \\
\text { Matematik }\end{array}$} & $\mathrm{N}$ & 31 & 31 & 31 & 31 & 31 & 31 \\
\hline & $\mathrm{X}_{\mathrm{mak}}$ & 29 & 83 & 0,81 & 26 & 70 & 0,69 \\
\hline & $\mathrm{X}_{\min }$ & 2 & 10 & $-0,8$ & 3 & 10 & $-0,6$ \\
\hline & $\overline{\mathrm{X}}$ & 10,65 & 35,03 & 0,2763 & 9,548 & 30,48 & 0,2270 \\
\hline & SD & 6,135 & 20,24 & 0,2155 & 5,195 & 15,56 & 0,1855 \\
\hline \multirow{5}{*}{$\begin{array}{l}\text { Kemampuan } \\
\text { Koneksi } \\
\text { Matematik }\end{array}$} & $\mathrm{N}$ & 31 & 31 & 31 & 31 & 31 & 31 \\
\hline & $\mathrm{X}_{\mathrm{mak}}$ & 9 & 65 & 0,62 & 11 & 40 & 0,36 \\
\hline & $\mathrm{X}_{\min }$ & 2 & 5 & $-0,03$ & 2 & 3 & 0,05 \\
\hline & $\overline{\mathrm{X}}$ & 5,710 & 19,74 & 0,1488 & 5,742 & 12,68 & 0,07319 \\
\hline & SD & 1,346 & 14,64 & 0,1561 & 1,914 & 8,700 & 0,09481 \\
\hline \multirow{5}{*}{$\begin{array}{l}\text { Kemampuan } \\
\text { Disposisi } \\
\text { Matematik }\end{array}$} & $\mathrm{N}$ & 31 & 31 & 31 & 31 & 31 & 31 \\
\hline & $\mathrm{X}_{\mathrm{mak}}$ & - & - & - & - & - & - \\
\hline & $\mathrm{X}_{\min }$ & - & - & - & - & - & - \\
\hline & $\overline{\mathrm{X}}$ & - & 79,90 & - & - & 81,42 & - \\
\hline & SD & - & 6,848 & - & - & 7,575 & - \\
\hline
\end{tabular}


Berdasarkan Tabel 4.1 memperlihatkan bahwa rataan skor pretes kemampuan komunikasi kelas eksperimen lebih besar dibandingkan dengan kelas kontrol yaitu kelas eksperimen 10,65 dan kelas kontrol 9,548. Perbedaannnya sekitar 1,102 ini menunjukan adanya perbedaan kemampuan awal kemampuan komunikasi matematik siswa. Sedangkan setelah dilaksanakan pembelajaran rataan skor postes kemampuan komunikasi matematik siswa kelas eksperimen 35,03 dan kelas kontrol 30,48 dan standar devisiasinya kelas eksperimen 20,24 dan kelas kontrol 15,56. Sehingga pada perhitungan standar deviasi skor postes kelas eksperimen dan kelas kontrol, terlihat bahwa penyebaran kemampuan komunikasi matematik siswa setelah pembelajaran menggunakan strategi Think Talk Write sama dengan pembelajaran biasa.

Berdasarkan Tabel 4.1 memperlihatkan bahwa rataan skor pretes kemampuan koneksi matematik kelas eksperimen 5,710 dan kelas kontrol 5,742. Perbedaannnya sekitar -0,032 ini menunjukan adanya perbedaan kemampuan awal kemampuan koneksi matematik siswa. Sedangkan setelah dilaksanakan pembelajaran rataan skor postes kemampuan koneksi matematik siswa kelas eksperimen 19,74 dan kelas kontrol 12,68 dan standar devisiasinya kelas eksperimen 14,64 dan kelas kontrol 8,700. Sehingga pada perhitungan standar deviasi skor postes kelas eksperimen dan kelas kontrol, terlihat bahwa penyebaran kemampuan koneksi matematik siswa setelah pembelajaran menggunakan strategi Think Talk Write lebih baik daripada pembelajaran biasa.

Selanjutnya akan dilakukan analisis data pretes dan postes untuk mengetahui kemampuan komunikasi dan koneksi serta disposisi matematik siswa. Kemudian dilakukan analisis gain ternormalisasi, dengan strategi Think Talk Write dan pembelajaran biasa untuk mengetahui peningkatan dan pencapaian kemampuan komunikasi dan koneksi matematik siswa. Untuk melihat signifikan atau tidaknya dilakuakn uji rataan, dengan terlebih dahulu dilakukan uji normalitas, uji homogenitas dan uji perbedaan dua rata-rata dengan derajat signifikansi 0,05 .

\section{SIMPULAN DAN SARAN}

Berdasarkan temuan dan pembahasan, penelitian ini memberikan suatu kesimpulan sebagai berikut. Peningkatan kemampuan komunikasi matematik siswa yang menggunakan pembelajaran TTW lebih baik dibandingkan dengan kemampuan pemahaman matematik siswa yang menggunakan pembelajaran konvesional. Peningkatan kemampuan koneksi matematik siswa dengan pembelajaran $T T W$ lebih baik dibandingkan dengan kemampuan komunikasi matematik siswa yang menggunakan pembelajaran konvesional.

Adapun saran yang dapat disampaikan diantaranya adalah sebagai berikut. Pengembangan kemampuan komunikasi dan koneksi matematik lebih diutamakan untuk 
materi matematika yang essensial dan disertai dengan penyediaan bahan ajar, LKS. Pada implementasi pembelajaran TTW, intervensi (scaffolding) dari guru sesuai dengan kebutuhan siswa. Siswa masih memerlukan waktu yang lama untuk memahami konsepkonsep matematika dan penerapannya terlebih pada berpikir kritis dan komunikasi matematik.

\section{UCAPAN TERIMA KASIH}

Penulis mengucapkan terimakasih kepada Dr. Sungkono, SE., MM. selaku Ketua Lembaga Penelitian dan Pengabdian pada Masyarakat Universitas Buana Perjuangan Karawang yang telah memberi arahan sehingga penelitian dapat selesai dengan baik, dan semua pihak yang telah membantu sehingga artikel ini dapat tersusun.

\section{DAFTAR PUSTAKA}

NCTM. 2000. Principles and Standards for School Mathematics. Reston: NCTM

Peraturan Menteri Pendidikan Nasional Nomor 22 Tahun 2006 Tentang Standar Isi untuk Satuan Pendidikan Dasar an Menengah. Jakarta : Depdiknas

Shadiq, F. (2007). Laporan Hasir Seminar Lokakarya Pembelajaran Matematika 15-16 Maret 2007 di P4TK Matematika Yogyakarta.

Wahyudin.(2008). Pemnelajaran dan Model-Model Pembelajaran (pelengkap untuk Meningkatkan Pedagogis Guru dan Calon Guru Profesional).Bandung:Belum dipublikasikan

Sumarmo, U. 2013. Kumpulan makalah Berpikir dan disposisi matematik serta pembelajarannya. FMIPA UPI. Bandung. 